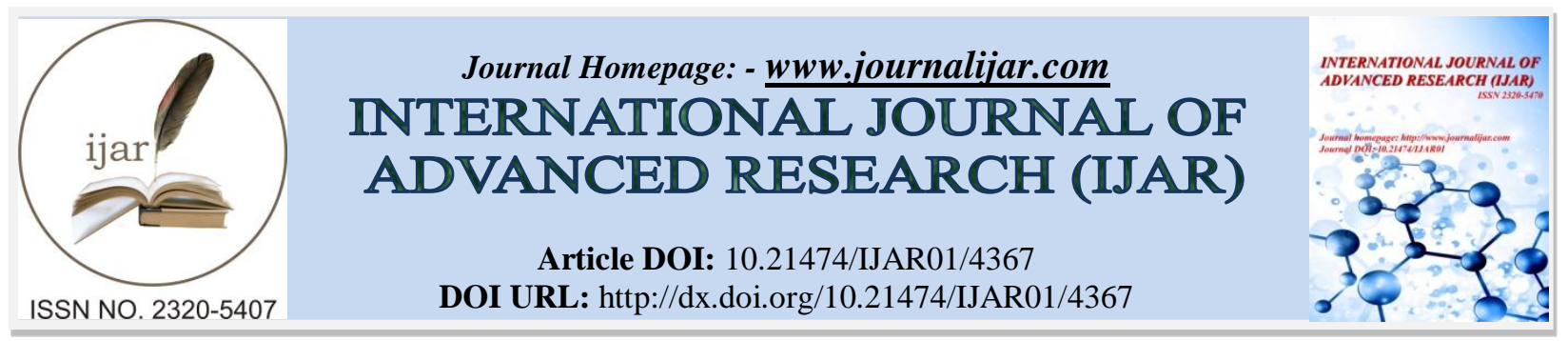

RESEARCH ARTICLE

\title{
EXPLORING THE LINKAGE BETWEEN GENDER, RELIGION, STATE AND NATION WITH SPECIAL REFERENCE TO ISLAMIC REPUBLIC OF IRAN .
}

\author{
Dr. Jyotika Teckchandani. \\ Assistant Professor, Amity Institute of Social Sciences, Amity University, Noida.
}

\begin{abstract}
Manuscript Info
Manuscript History

Received: 24 March 2017

Final Accepted: 22 April 2017

Published: May 2017
\end{abstract}

Abstract

\section{Meaning of Gender:-}

Gender refers to the cultural ideas that normatively order images and expectations on the basis of socially defined masculinity and feminity. Gender plays a pivotal role in the ordering of the society through various forms of gendering, refashioning of structures of patriarchy, contestation over gender roles and struggle over sexuality and its use as an identity marker for the collective. As Judith Lorber puts it, gender is "a process of social construction, a system of social stratification and an institution that structures every aspect of our lives because of its embedment in the family, the workplace, and the state as well as in sexuality, language and culture."

Social identification of sexes is important primarily because it reflects how a society construes and constructs sex and gender. Gender relations and the meaning of gender identity change in accordance with changes in access of men and women to various social resources. Gender, as Butler has argued is neither an essence nor an objective, external ideal to accomplish; it is, rather performative that is, created by the very acts of gender. Gender is a construction that regularly conceals its genesis. ${ }^{2}$ Because of its contingent, relational nature, gender is not always acted out consistently; socially acceptable gender identity is never fully attained. Socially defined gender denotes power as central to making gender relations and identities. Power operates through multiple mechanisms and is never completely unidirectional. ${ }^{3}$ In interaction between the sexes the power is often negotiated through the articulation of specific gender definitions.

Gender does not only refer to what men and women are biologically but, to the ideological (or discursive) and material relations also that exist between groups of people called 'men' and people called 'women.' The terms 'masculine' and 'feminine' do not describe natural characteristics but are gender terms. In all societies and in all cultures there are emotional and psychological characteristics that are held to be essentially male or female.

${ }^{1}$ Lorber, Judith.1994.Paradoxes of Gender. p.5. New Haven, CT: Yale Press.

2 Butler, Judith.1990.Gender Trouble: Feminism and the Subversion of Identity.p.140.New York: Routledge.

3 Shahidian, Hammed.2002.Gender Politics in Islamic Republic. p 5.Greenwood Press, London.

Address:- Assistant Professor, Amity Institute of Social Sciences, Amity University, Noida. 
Similarly, when sex and gender do not coincide naturally, individuals who are born as males and females are usually expected to develop masculine or feminine character traits and behave in ways appropriate to their gender. Like for example, women are considered to be more passive, emotional and sensitive than men and that men by contrast are considered more aggressive, rational and logical. This notion has been used to justify gender inequality and female subordination to male authority. Feminists have pointed out that rather than reflecting the personality traits of men and women, ideas about gender have been used to justify unequal treatment and thus provided an important ideological justification for a specific form of social inequality. ${ }^{4}$

The view of gender as social and not natural points to the importance of discursive constructions or inter-subjective understanding of gender, that is, the social meaning and significance attributed to perceived sex differences. Gender is material in a sense that even while one's gender is not necessarily rooted in the materiality of ones sexed body, it is nevertheless embedded in social institutions and practices that reproduce gender identities, gender roles and gender relations. Hence, in any society one's gender will influence one's entitlement to concrete resources and will be a crucial factor in deciding who gets what, but also who can do what one is permitted to 'be' in any given society. ${ }^{5}$ Thus, Gender also intertwines with class, ethnicity, race, sexual orientations, beliefs and ideological commitments.

\section{Religion, Gender and Sexuality: Exploring the Intricate Relationship:-}

Sexuality is one of the most powerful dimensions of individual and inter-subjective human life. The act of sexual intercourse between two consulting adults is not only a source of erotic pleasure but also creates a lifelong emotional bond with a potential to beget a new life and reproduce kinship structures and social reproduction. For this reason sexuality is considered the most intimate expression of the embodied self the most private of affairs and the primary source of socio-biological reproduction and therefore a public affair which no society can leave unregulated. ${ }^{6}$

Religions are discursive systems of beliefs and practices $^{7}$ that offer structures of moral order, meaning weaving discourse of life through means of transcendental communication with divine reality. Religions have historically been involved in the regulation of sexuality, biological and social reproduction, and family structure and gender relations on the basis of its transcendental principle as natural, sacred or of divine origin. The industrialization of economy and modern democratic value system has brought a fundamental transformation in the conception of sexual orientation, gender relations and gender roles that is threatening the epistemological foundation of all religious traditions, particularly the monotheistic religious traditions. Thus, almost all religions are opposed to homosexual or uni- sexual marriage. It is not without reason that many scholars see the Islamic revolution as a brutal, patriarchal attempt to control the increasing assertion of sexual freedom of Iranian women. ${ }^{8}$ In fact it is not surprising that many analysts see the resurgence of religious "fundamentalism" at global level primarily as a patriarchal reaction to the growing worldwide assertion of gender equality and feminism. ${ }^{9}$

In this context patriarchy, as Walby suggests, underwent a series of modifications in the past two centuries partly in response to women's demands for equal status in society, and partly in response to increase the control of the state over all aspects of social life. ${ }^{10}$ In the area of employment women were no longer barred from certain professions;

4 Steans, Jill.2006.Gender and International Relations.p.9.Polity Press.

5 Ibid, 8

6 Casanova, Jose. Religion, Politics and Gender Equality Public Religions Revisited.p.15 Available at: www.unrisd.org/80256B3C005BCCF9/.../\$file/WEBCasvadrftII.pdf accessed on 2.3.2014

7 See for details, Assad, Talal.1993. Genealogies of Religion: Discipline and Reasons of Power in Christianity and Islam. Baltimore: The John Hopkins University Press.

8 For details see Fathi, Asghar. 1997. Women and the Family in Iran. Brill Academic Publishers., Moallem, Minoo.2005. Between Warrior Brother and Veiled Sister: Islamic Fundamentalism and the Politics of Patriarchy in Iran. University of California Press.

9 Riesebrodt, Martin.1998.Pious Passion: The Emergence of Modern Fundamentalism in the United States and Iran. Berkeley, CA: University of California Press.

10 Walby, Sylvia.1994.Theorizing Patriarchy.p.179.Cambridge, MA: Blackwell. 
they were instead confined to jobs segregated from and valued less than those of men. The exclusion of women from political and cultural realms has been replaced by their subordination. Thus, the control over female sexuality has shifted from the exclusive control of father, husband or brother to that of a broader public arena. In public patriarchy, the expropriation of women has been effected more collectively than by individual patriarchs. The shift in the site of sexual domination from private to public is accompanied by a change in patriarchal strategy from exclusion to segregation and subordination whereby women are no longer barred from economic, cultural, and political institutions, but their domains of their involvement are segregated from and graded lower than those of men. " Gender or the 'Woman question' has become in this respect the preeminently contested "social question", while "religion" has been thrown, willingly or unwillingly, into the vortex of the global contestation. ${ }^{12}$

In order to structure the relationship between the gender, sexuality and religion Birgit Heller ${ }^{13}$ provides an useful tripartite analytical differentiation between: a) the issue of women's status and roles in different religious traditions, that is, the kinds of institutionalized gendered religious division of labor within particular religious regimes; b) the subject of cultural images, ideas, stereotypes and norms about women within diverse discursive religious traditions; and c) the question what women as religious subjects do and think.

\section{The Gendered Religious Division of Labor and Power Relations within Religious Regimes:-}

Sociologically speaking, one can understand the institutionalized religions as religious regimes having a system of production, consumptions, and distribution of power, authority, and decision making within a community in relation to what is considered the 'sacred' good, In this context one relevant question that arises here pertains to access and share of specific gender in the system of production, distribution and consumption of religious goods ${ }^{14}$. In other words how gendered is the distribution of symbolic power and resources in a religious regime? Though all monotheistic religions including Islam treat believer equally irrespective of gender and they are all equal in the eyes of God. Casanova has rightly noted that, "God is the source and model of equitable justice and fairness to all. Moreover, as 'the most Merciful and Compassionate,' God is considered to look after for the weak, the poor, the meek, the orphan, the widow etc. This is the core prophetic ethical norm that anticipates modern gendered equality as a transcendent principle." 15

However, notwithstanding the notion of equality, fairness and justice being the integral part of all monotheistic religions, the institutionalized religious system everywhere in its operational reality is characterized by unequal access to divine knowledge and distribution of divine resources. With the passage of time as the religious systems became routinized it acquired the patriarchal values as the basic principles of religion. One consequence of this process is the gradual development of unequal access along gender and class line to religious resources. Thus the priesthood in the case of the Catholic Church, and to some extent the Ulama ${ }^{16}$ in the case of Islam, as hierarchically differentiated and high status religious roles, is exclusively male, ${ }^{17}$ though female assertion in this role is emerging. Further, though Islam paid special importance to equality to gender and individual women had close access to Prophet Muhammad and played important roles in the history of Islam, however the later development of institutionalized Islamic tradition did marginalize the status of women in Muslim societies. In the specific context of

11 Ibid, 179

12 Casanova,no.6.p.16

13 The classification has been taken from Casanova, Jose.no.6. Citing Birgit, Heller. 'Gender and Religion.' In Børresen Kari Elisabeth (ed). 2001. Gender and Religion. p 357-59. Roma: Carocci editore.

14 Ibid

15 Ibid

16 Ulama ( singular alim) does not constitute a pristly class in Muslim society, as there is no Church in Islam. However, as Ulema came to identify themselves as custodian of Prophetic traditions and carries the main responsibility to convey the correct message of Prophet (dawa), they have functioned as clerical class.

17 Casanova,no.6.p.18 
Iranian Shi' $i$ Islam where there did develop a highly differentiated and hierarchically organized structure ${ }^{18}$ but there is hardly any women ayatollah or hojatoleslam in the Iranian society. The issue of representation of women in the ulema class is increasing. Amina Wadud, in the United States even led the mixed gender namaz congregation with her being the Imam. ${ }^{19}$ In this context, pious veiled Muslim women becoming ever more visible in the public sphere of Muslim societies and increasingly attending mosque services can be interpreted actually as a sign of increasing religious gendered equality, and thus as evidence of the modernization of Islam under the pressure of modern gender democracy rather than as a fundamentalist reaction to modernity. ${ }^{20}$ In this respect, it can be read as evidence of the pressure of global secular norms upon all religious traditions.

This raises a fundamental question with regard to the proper boundary between the private and public or between religious and secular spheres. Though modernity has sharpened the private/public dichotomy, the boundary between the two is historically and culturally contingent, fuzzy in nature and therefore has been open to continuous public contestation and redrawing. Thus what is considered 'private' under secular dispensation might appear to be 'public' from religious point of view. For instance 'sexual morality' is strictly a private affair under secular order but for religious people it is a 'public' matter. Thus, the public debates surrounding over abortion, conversion, blasphemy, multiculturalism, polygamy, women rights, lesbian and gay rights do not allow for simple, straightforward, uncontroversial answers but rather varies from society to society. For the same reasons many aspects connected with universal human rights are subject to sharp religious and cultural contestation.

\section{Religion and Sexism: Representation of Women in Religious Traditions:-}

The issue of relationship between religion and sexuality concerns the issue of representation of women in religious tradition. Therefore it is important to find out how women have been represented in Islamic tradition. Historically speaking, Qur'an is gender neutral and speaks equality of sexes in clear terms. Today there is an intense debate among Muslim intelligentsia including ulema concerning the proper representation of women within Islam. While there is an emerging consensus about the marginalized position of women in Muslim society, there is a less consensus whether Islam had any role in legitimating the gender inequality within Muslim societies. The dominant Muslim intelligentsia tends to blame the conservative role of Ulema and misrepresentation of Islamic traditions. However, there is an emerging minority view that argues that the Prophetic Revelation and the Sunnah of the Prophet did not constitute an improvement in the situation of women when compared with the reigning conditions in the immediate pre-Islamic period in the Arabian Peninsula. ${ }^{21}$ It is more widely accepted that Muhammad himself respected and trusted women and tried to provide for equal participation of women in the religious life of the ummah. $^{22}$ On the other hand, there is evidence for a rapid decline with the institutionalization of the early Muslim community, marked by what Jane Smith has termed a dual process of "exclusion" and "seclusion," that is, the exclusion of women not only from leadership roles but also from the communal aspects of religious life and their seclusion to a place apart from normal social intercourse with men. ${ }^{23}$

\section{Ibid}

19 Wadud, Amina, a Professor in the USA led the mixed gender Friday prayer in a mosque of New York in 2005. See 'Woman leads US Muslims to prayer.' Available at:

http://news.bbc.co.uk/2/hi/americas/4361931.stm accessed on 27. 10.2013.

20 Casanova,no.6.p.19

21 For details see Ahmed, Leila.1992. Women and Gender in Islam: Historical Roots of Modern Debate. New Haven: Yale University Press; Stowasser, Barbara Freyer.1994. Women in the Qur'an, Traditions, and Interpretation. New York: Oxford University Press. Wadud, Amina.1999. Qur'an and Woman: Re-Reading the Sacred Text from a Woman's Perspective. New York: Oxford University Press.

\section{Ibid}

23 For details see Smith, Jane I. 'Women, Religion and Social Change in Early Islam.' In Yvonne Yazbeck Haddad and Ellison Banks Findly (ed.) 1985. Women, Religion, and Social Change. pp. 19-31.Albany: SUNY Press. 
In this regard the most heated controversies are about the role of veiling as a marker and assertion of Muslim identity in the increasingly globalized world. Veiling, above all, has become the most salient, contested, and controversial emblem of contemporary global Islam. As Nilüfer Göle has pointed out, "no other symbol than the veil reconstructs with such a force the 'otherness' of Islam to the West. Women's bodies and sexuality reappear as a political site of difference and resistance to the homogenizing and egalitarian forces of Western modernity." ${ }^{24}$ Though in the western imagination the "headscarf" signifies the subordination of women in the Muslim society. Though in part this reflects the western sensibility of notion of equality, but in part also functions as marker of differentiation from Muslim society. Thus, one finds a plethora of works that have questioned such a simplistic liberal, feminist and secularist reading of the phenomenon of veiling in the Muslim societies and offer a more nuanced, ambivalent, and contextual interpretations ${ }^{25}$. Indeed, throughout the Muslim world, particularly in the Middle East including Iran, the veil has functioned as power enabling the Muslim women to participate in the public sphere with greater freedom and assertion, a marker of Muslim subjectivity and cultural authenticity and differentiation from other civilization.

However, notwithstanding the 'thrust of equality' embedded in the narratives of Great Textual Tradition, the vernacularization of almost all religious texts and traditions has resulted in making women and the family a crucial symbolic factor in constructing group solidarity vis-à-vis wider society in most of religious traditions. ${ }^{26}$ Under such conditions, women's behavior and conducts becomes a symbol of group integrity. This partly explains the dominant representation of women in all religious traditions as mothers, caregivers, educators, and moral guardians and gradual transformation of women as inviolable repository of 'authentic' group identity. This valorization occurs through carefully crafted binary codes of 'respectable' behavior: the female group member ought to be veiled (versus exposed), modest (versus promiscuous), loyal (versus morally corrupt), married (versus sexualized), fertile (versus childless), and so on. ${ }^{27}$ Thus in the Islamic Republic of Iran (IRI), and in other Muslim countries, heterosexuality is considered as the proper gender behavior and all other kinds of sexual orientations, behavior or relations are either banned or criminalized. Only heterosexuality can reproduce and regulate the nation in all Muslim societies including Islamic Republic of Iran. ${ }^{28}$

Women as Religious Subjects, Historical Agents, and Political Actors:-

The proliferation of feminist religious discourses in recent years reflects a desire of women for radical transformations in religious traditions in order to achieve the goal of equity and justice. Islam is no exception to this emerging trend as evident for the proliferation of Islamic feminist writings. ${ }^{29}$ At the same time, these attempts of feminist writings to restructure the religious politics of gender have evoked sharp internal contestations and debates. ${ }^{30}$ Certainly in recent years in the Muslim societies, a good number of women has embarked on reading and understanding the sacred texts without the mediation, interpretation, and control of male religious authorities, which

24 This has been taken from Casonova, no.6. Citing Göle, Nilüfer. The Forbidden Modern. Civilization and Veiling . 1995. p. 1. Ann Arbor: The University of Michigan Press.

25 See, Mahmood, Saba. 2005. Politics of Piety: The Islamic Revival and the Feminist Subject. Princeton: Princeton University Press. Also, Hosseini, Ziba Mir. 1999. Islam and Gender. The Religious Debate in Contemporary Islam. Princeton: Princeton University Press.

26 Some of good literature on this subject matter is Shachar, Ayelet. 2001. Multicultural Jurisdictions: Cultural Differences and Women's Rights. p 45-62. Cambridge: Cambridge University Press. Kandiyoti, Deniz (ed).1991.Women, Islam and State. London: Macmillan Press.

27Shachar,Ayelet. 'Religion, State, and the Problem of Gender: New Modes of Citizenship and Governance in Diverse Societies.'p.3.Available at:

lawjournal.mcgill.ca/userfiles/other/410530-1225240850_Shachar.pdf accessed on 25.2.2014.

28 Shahidian, no.3. p 9.

29 Casanova,no.6.p.24

30 Ibid 
indicates a first hermeneutics step on the road to female religious subjectivity and agency. It is on this complex relation between gender, morality, religion, feminism and secularization that one can observe very different dynamics throughout the Muslim world. Indeed, as Saba Mahmood has pointed out, "the vexing relationship between feminism and religion is perhaps most manifest in discussions of Islam." ${ }^{\text {31 }}$ Muslim women not only have entered the mosque, but are in many cases leaders of the modern mosque movement, thereby challenging the traditional image of the mosque, and the ummah, as a public male assembly. ${ }^{32}$ Further, the female veil is becoming the public face of global Islam.

It is precisely this public manifestation of female agency and subjectivity and the grassroots character of the mass movement that baffles liberal and secular feminist assumptions as well as our conceptions of a modern civil society. As Mahmood has asked rhetorically: "why would such a large number of women across the Muslim world actively support a movement that seems inimical to their 'own interests and agendas,' especially at a historical moment when these women appear to have more emancipatory possibilities available to them?"33 The fact that the movement also enjoys support from highly educated and articulated women from the upper and middle-income strata of many Muslim societies, makes explanations in terms of "false consciousness" "self-imposed tutelage" or the "feminist intuition" that women (like men) can internalize norms that lead to their own oppression, even more problematic. ${ }^{34}$

Relationship between Gender, Nation and State:-

Feminist scholars Nira-Yuval Davis ${ }^{35}$, Floya Anthias ${ }^{36}$ and Jill Steans ${ }^{37}$ have shown the relevance of gender relations in the construction of the nation and underlined the significance of women, sexuality and the family as symbols in the reproduction of the nation and its boundaries. It is not uncommon to find out that the nation is depicted as woman. The deeply ingrained image of homeland as a female body whose violations by foreigners require citizens to rush to her defense is a powerful image in nationalist ideology. This depends upon the image of woman as chaste and dutiful. Not only the nationalism is couched in terms of love of country but also within this imaging of the nation, women, serve as the repository of group identity. National identity is equated with ideas about gender, parentage and skin colour. Women not only bear the burden of being the mothers of the nation but their bodies may also be used to reproduce the boundaries of the national group, transmit its culture and become the privileged signifiers of national difference. ${ }^{38}$

The power of nation lies in its appeal to a sense of belonging of being at home. The identification of women with the private domain of the home and family reinforces the powerful imagery of a national community with that of the selfless/devoted mother. ${ }^{39}$ This automatically triggers response that one should be ready to sacrifice himself or herself in defence of her chastity and honour. The symbolic connection between the idea of woman and the idea of nation and the use of women as symbols of nations by nationalist and liberationist movements has been critical to the gendering of women's membership in national communities. Despite the diversity of identities and loyalties in any specific nation, the ideal of 'woman' has fueled the ideals of 'authentic' national cultures, 'indigenous' religions, 'traditional' family forms. The category of 'woman', as a stand-in for 'nation, 'has been marketed to

${ }^{31}$ Mahmood, no.25.p.1

32 Wadud,no.19

33 Mahmood, no.25. p. 2.

34 Casanova,no.6.p.28

35 See Davis, Nira Yuval and Floya ,Anthias (eds.) 1989. Woman-Nation-State. London: Macmillan.

$36 \mathrm{ibid}$

37 Steans, no.4.p.3

38 For the above paragraph see Ibid,40

39 For details see Steans,no.4.p.55 
delineate 'national' boundaries. ${ }^{40}$ Such usage of 'woman' has gone hand in hand with the imposition of forms of behavioral control on women in the name of the nation, in the name of liberation, in the name of progress, and in the name of God. Thus, the Nations, seen as imagined communities, to use Anderson phrase, ${ }^{41}$ use "the woman" as a critical symbol in inventing their notions of themselves.

The metatmorphization of nation as women is grounded in patriarchal relationships. Consequently, the female body becomes the battleground not only for countries and their enemies, but also for competing definitions of' national identity. ${ }^{42}$ Preserving a pure national identity becomes equivalent to protecting and controlling women's sexuality. ${ }^{43}$ Control of women's sexuality has become a core of the power struggle between the ideologically rival groups in the political system. The state has played an important role in modifying and restructuring gender relations and women's sexuality. Thus, in its attempt to Islamize the women's position, the IRI resorted to coercion, passed inegalitarian laws and mobilized female morality squads to enforce its codes of propriety in order to imagine its own version of Islamic nation. ${ }^{44}$

The family constituted the basis of society in which the women played the most important role as mothers. Women were regarded as transmitters of communal and national values to their next generation. As a result the preservation of the status quo and the change were linked to the position of women. Women were constructed as reproducers of communal, national and religious identity. ${ }^{45}$ Women's behavior, clothing, patterns of reproduction, life style and ways of thinking were all regarded as symbols of communal identity and markers of national boundaries.

The above linkage between gender and nation is mediated through the administrative agency of state. As the identity of nation is far from settled in most of societies, particularly in post- colonial societies, it is the state that fashion and refashions the construction of nation building in the societies. It is in the process of nation building that state differentially impacts on the gender relationship in the society depending upon its ideological world view, social base and nature of factional politics. Further most of the state policies are justified in the name of 'national interest' or to build a powerful nation. In this sense nation emerges as modern legitimizing category for contraction and expansion of gender specific rights depending upon the context.

States intervene in women's lives for the purpose of internal and external policy. Internationally, the state uses women and their portrayal as westernized and Islamized, veiled or unveiled in order to depict a distinct political identity and message abroad. Domestically, whether weak or strong, secular or religious the political regime manipulates women's sexuality and their labor in order to legitimize its cultural and political position and to consolidate its power. Depending upon the ideological propensities and material social base state unleashes the programme for expanding or contracting gender specific opportunity structure. In the process state sets an agenda for the control of particular class of women or their activities. It builds alliances with different classes of women especially in their policies of mobilization. Gender can have a huge influence in policy making and functioning of the State. Gender remains a core concern of politics. Gender analysis illuminates politics and power struggle: who gets what, when, how and why. ${ }^{46}$

40 Joseph,Suad. 'Gender and Citizenship in the Arab World.'Available at:

http://iwsaw.lau.edu.lb/publications/al-raida/citizenship-and-gender-in-the.php accessed on 5.3.2014

41 Anderson, Benedict.2007. Imagined Communities: Reflections on the Origin and Spread of Nationalism. Verso Books.

42 Shahidian,no.3. p19

43 Ibid

44 Ibid

45 See Davis, Nira Yuval and Floya ,Anthias.no.35.p.7

46 For the above paragraph see Sedghi, Hamideh.2007. Women and Politics in Iran: Veiling, Unveiling, and Reveiling.p.2-8. Cambridge University Press. 
The state has no fixed relationship to the gender; it is evolving, dialectic and dynamic ${ }^{47}$ because the state is not a single-minded actor with a unified set of interests. States are composed of different, conflicting, and changing sets of interests. The state, in fact, is a contested terrain, its actions reflects local, national, and global conflicts and contradictions. The state policies construct men and women differently. Women on the one hand are constructed like men as citizens. But they are also treated a special category in relation to various roles they play in society. Women are assigned status as mothers and revered as symbols of national and communal identity. ${ }^{48}$ Rights and responsibilities of the women are often defined by the state. The state therefore partly reflects and creates particular forms of gender inequality and gender relations. Gendered identities are in part constructed by the law and public discourses, which emanate from the state.

Although the state has the ability to modify and reshape gender relations and women's lives but at times its actions are also shaped by the persistence of women's resistance. As active and reactive agents of social change, women respond to and defy state actions. Women pose challenges to the system, sometimes successfully, sometimes not. ${ }^{49}$ Women's responses vary historically; it varies not only by their class background, ideological dispositions, and religious outlook, but also by the degree of their political and feminist awareness and how well they can articulate their interests and issues of their concerns.

As Shirin Rai ${ }^{50}$ argues that the relationship between the state and gender is not fixed and immutable, battles can be fought out in the arena of the state. Consequently, the state has for most part acted to reinforce female subordination; the space can exist within the state to act to change gender relation. Women's relationship to the state can also be seen as a site of contestation which provides the context for mobilization, and the state can function as a locus of resistance. The policies of the state and their impact on women are generally divided into three major categories. The first set is the policies which are aimed fundamentally at women. These often focus the so called protective legislation and reproduction, e.g abortion laws and laws surroundings childbirth such as provision of maternity leave. A second subdivision is those policies which refer to the relation between men and women, particularly property rights, family relations, labour laws, areas where power relations between men and women are and therefore set off gender relations are often institutionalized. The law and regulation surrounding these issues become an area of contestation when attempts are made to alter the existing pattern of power relationships as occurred and women's mobility become highly contested. The third set of policies -general and gender neutral- have and different impact on women and men. This involves the developmental programme of the government such as setting up industry, communication, transportation, Defence, law and order machinery, education etc that are conceived in gender-neutral framework but have differential impact on gender. ${ }^{51}$

\section{Gender, Islam and State in Islamic Republic of Iran:-}

It is within the above theoretical formulation that the issue of relationship between gender, Islam and state in post revolutionary Iran has been analyzed in the following chapters of the thesis. The duality of Iranian political structure further complicates the analysis of gender relationship in post revolutionary Iran. Notwithstanding the limitation of dual structure, the key to understanding the gender discourse in Islamic Republic of Iran is interpretative field of Islam that legitimizes and delegitimizes various actions of state including its gender related programme and policies.

Women's issues in Iran became all the more important because Iranian society in this period underwent a rare historical moment, a moment of revolution and of restructuring of state and society in the aftermath of revolution. It was during this period that various principles and organs of Islamic state in Iran were institutionalized under the

47 For the above paragraph see Waylen, Georgina. 'Analysing women in Third World Politics.' In Haleh Afsar Women and Politics in Third World.1996 (ed) .p.15. Routledge.

48 Paider, Parvin.1995. Women and the Political Process in Twentieth Century Iran.p.22. Cambridge: Cambridge University Press.

49 Sedghi, no.46.p.4

50 Rai,Shirin. 1996. 'Women and the state in the Third World.' In Haleh Afsar Women and Politics in Third World (ed) p. 13.Routledge.

51 For the above paragraph see Waylen,no.47.p.13. 
supervision of late Imam Khomeini, the founder of Islamic Republic of Iran. Women affected the national processes in the same way as much they were affected by them.

The Islamic state's mission has been to create an ideal Islamic society wherein women and men can accomplish their holy duties. As the family is regarded as the microcosm of society IRI has considered it pivotal to 'strengthen the family' that is, to emphasize the primacy of the women's domestic roles and to secure men's position as the head of the household. In the Islamic state, individuals ought to belong to 'right' gender and must have the 'right gender interaction'. Gender and politics become inter-wined: correct politics creates correct gender and correct gender increases one's chances in the social and the political arenas. ${ }^{52}$

The prominent place given to the women and family in the Constitution of IRI reflected the depth of interest expressed by all competing ideologies in the relationship between the gender and nation. The Constitution clearly demonstrated that the Islamic nation was dependent on the Islamization of gender relations. It constructed a new 'Islamic' link between nation and gender and specified a corresponding position for women. Women were constructed as citizens in the interest of the nation building, but they were also defined in their special roles within the state and community. Women were defined as biological reproducers of the community and nation and were assigned roles on this basis. In post revolutionary Iran, the authorities explicitly define the parameters of gender appearances. The law prohibits a range of gender-inappropriate behaviors (e.g.; long hair for men, unladylike comportment for women) and deviant clothes like see-through, short scarves that do not completely cover hair and neck, anklets, sunglasses ${ }^{53}$ Control of women's sexuality is viewed to be another aim of the Islamic state. As Fatima Mernissi has noted that the sexual power attributed to women has caused the Islamic states to contain and control their sexuality through such social institutions such as the veil, the family, the marriage system and the legal system. $^{54}$

The Islamists came to power following the decades of refashioning patriarchy that afforded women greater freedom and mobility and curbed men's power within the family. The IRI has sought to reinforce male dominance within the family, reinstate men's prerogative compromised under the Pahlavi's, and define women primarily in their private roles of wife and mother. Women's social role in the pre revolutionary Iran has made it impossible to send women back to their homes. Though successful in passing legislation that limit's women options, state has been forced to accept women's limited public presence, so as long as it did not interfere with their familial duties.

The discourse on gender relations in post-revolutionary Iran is very complex and cuts the dominant binary framework of tradition vs. modernity. The thrust of state-mediated gender discourse have been marked by contradictory pulls and pressures of confining the dominant role of women to private sphere while offering the limited role in political-public sphere. The Islamic Republic did not inherit a ready- made Islamic policy on gender. The dominant conceptions of gender were constructed as events developed in post-revolutionary society. Thus the gender relations in IRI can also be understood in terms of conflictual between conservative ulema who opt for larger domestication of women and the progressive ulema who fight to safeguard and expand their rights. Hence, the variations within Islamic interpretation over the role of gender must be taken into consideration while analyzing the relationship between gender and state in post-revolutionary Iran.

52 For the above paragraph see Shahidian,no.3.p.213

53 Ibid, p.166-170

54 Mernissi, Fatima.1975.Beyond the Veil: Male-Female Dynamics in a Modern Muslim Society. pp.xv. Second Edition. Bloomington: Indiana University Press. 